\title{
Towards a landscape archaeology of Buddhist cave-temples in China
}

\author{
Francesca Monteith*
}

Buddhism spread from northern India throughout the Asian continent from the first century BC onwards. As it spread, it changed and adapted to suit the new peoples and customs with which it came into contact. In recent years, studies have been undertaken on the landscape archaeology of Indian, Central Asian and Southeast Asian Buddhism. By focusing on China, this study represents a preliminary step in attempting to illuminate a new aspect of early Buddhist practice in China. It considers the chronological implications of the way in which the sites are positioned within the landscape. The study is based on survey work and site visits undertaken over the last five years, during the course of which certain patterns began to emerge. Based on these observations, an initial hypothesis was formed which states that the visibility of the locations into which cave sites are carved increases over time. Visibility is taken as the presence or prominence of a site within the physical landscape. This study focuses only on rock-cut cave-temples because they can still be clearly seen within their (nearly) original landscape settings. They can also be dated with relative accuracy on stylistic grounds. The same cannot be said of surface religious structures.

Although the earliest historical reference to Buddhism in China is from $65 \mathrm{BC}$, the earliest Buddhist artefact with a Chinese inscription dates to 312 BC (Rhie 2010). In northern China, Buddhism was adopted as the state religion by the 'foreign' Touba rulers of the Northern Wei (AD 386-535). Although Buddhism was present in the Jiangsu region during this time period, it was not until the end of the Northern Wei that traces of Buddhism started to occur in Northern Sichuan and the Chengdu region (Wei 2013: 510-15). The first references to the presence of Buddhist monks in south-eastern Sichuan date to the Sui (AD 581-618), but the earliest sculptures date to the Tang (AD 618-907). It is, therefore, one of the last regions in China to adopt Buddhism.

This pilot study focuses on the visibility of the cave-temples, and is based on sites that have been visited by the author, thus allowing for a consistent assessment of said visibility. The majority of the sites are in the Longdong region of Gansu and Rongxian County in Sichuan. These two areas form the basis of the author's PhD studies and have therefore been surveyed in full. Other, more well-known sites, also visited by the author, have been included to increase the sample size. There are 43 sites (Figure 1; Table 1), which date from the Northern Wei through to the Tang (386-907 AD). The location and date of a site are taken to be that of the earliest construction(s) therein.

Cave-temples are carved into cliff faces and rocky crags. Although this limits where they can be carved, there is some degree of flexibility for the location and size of the cave-temple,

* School of Archaeology and Museology, Peking University, 5 Yiheyuan Lu, Haidian District, Beijing 100871, China (Email: fcmonteith@pku.edu.cn) 


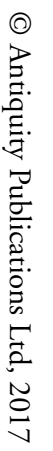

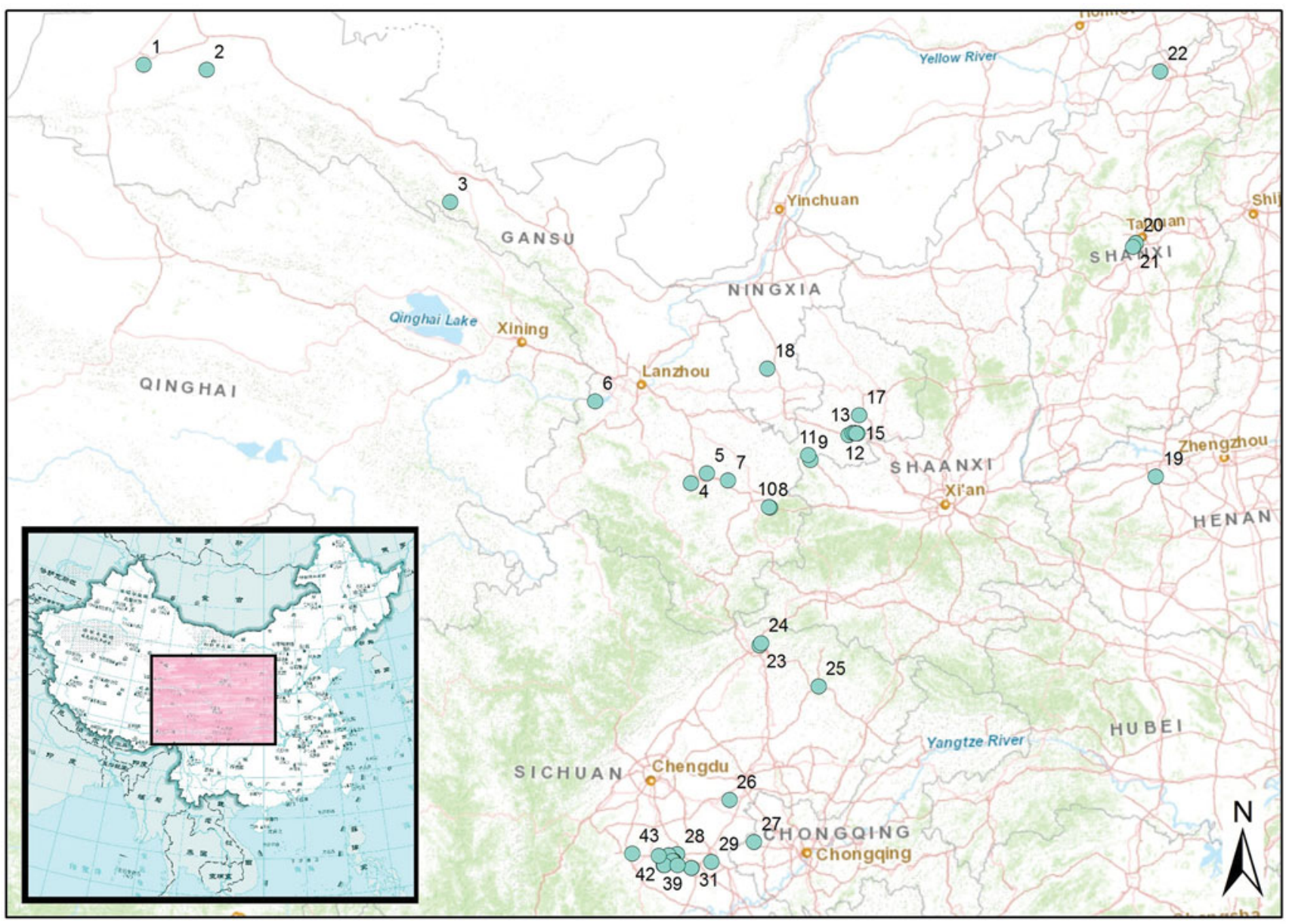

Kilometres

$0 \quad 50100 \quad 200300 \quad 400$

Figure 1. Map of China showing the locations of the cave-temple sites. 
Table 1. Site data.

\begin{tabular}{|c|c|c|c|c|c|c|c|c|}
\hline Map no. & Cave temple & 中文名 & Location & Northing* & Easting & Dynastic dating & Phase & Visibility \\
\hline 1 & Mogao Shiku & 莫高 & Dunhuang, Gansu & $40.04118^{\circ} \mathrm{N}$ & $94.80484^{\circ} \mathrm{E}$ & Xi Qin & Early & 1 \\
\hline 2 & Yulin Shiku & 千佛寺 & Yulin, Gansu & $40.06072^{\circ} \mathrm{N}$ & $95.93275^{\circ} \mathrm{E}$ & Northern Wei & Early & 1 \\
\hline 3 & Mati Si & 马蹄寺 & Zhangye, Gansu & $38.50111^{\circ} \mathrm{N}$ & $100.4249^{\circ} \mathrm{E}$ & Northern Wei & Early & 2 \\
\hline 4 & Muti Si & 木梯寺 & Tianshui, Gansu & $34.69386^{\circ} \mathrm{N}$ & $104.6881^{\circ} \mathrm{E}$ & Tang & Late & 2 \\
\hline 5 & Shuilian Dong & 水帘洞 & Tianshui, Gansu & $34.83264^{\circ} \mathrm{N}$ & $104.9512^{\circ} \mathrm{E}$ & Northern Wei & Early & 1 \\
\hline 6 & Bingling Si & 炳灵寺 & Linxia, Gansu & $35.81033^{\circ} \mathrm{N}$ & $103.0483^{\circ} \mathrm{E}$ & Xi Qin & Early & 1 \\
\hline 7 & Daxiang Shan & 大象山 & Tianshui, Gansu & $34.73279^{\circ} \mathrm{N}$ & $105.3104^{\circ} \mathrm{E}$ & Tang & Late & $3 b$ \\
\hline 8 & Maiji Shan & 麦积山 & Tianshui, Gansu & $34.35167^{\circ} \mathrm{N}$ & $106.0038^{\circ} \mathrm{E}$ & Northern Wei & Early & $3 a$ \\
\hline 9 & Yuyan Si & 龙门洞 & Qingyang, Gansu & $35.00253^{\circ} \mathrm{N}$ & $106.6928^{\circ} \mathrm{E}$ & Northern Wei & Early & 1 \\
\hline 10 & Xianren Ya & 仙人崖 & Tianshui, Gansu & $34.35609^{\circ} \mathrm{N}$ & $105.9936^{\circ} \mathrm{E}$ & Northern Wei & Early & 1 \\
\hline 11 & Shigong Si & 石拱寺 & Longdong, Gansu & $35.07473^{\circ} \mathrm{N}$ & $106.6572^{\circ} \mathrm{E}$ & Northern Wei & Early & 2 \\
\hline 12 & Wangmu Gong & 王母宫 & Longdong, Gansu & $35.33621^{\circ} \mathrm{N}$ & $107.3508^{\circ} \mathrm{E}$ & Northern Wei & Early & $3 b$ \\
\hline 13 & Fenghuang Gou & 凤凰沟 & Longdong, Gansu & $35.36701^{\circ} \mathrm{N}$ & $107.4134^{\circ} \mathrm{E}$ & Northern Wei & Early & 1 \\
\hline 14 & Nan Shiku & 南石窟 & Longdong, Gansu & $35.36352^{\circ} \mathrm{N}$ & $107.4486^{\circ} \mathrm{E}$ & Northern Wei & Early & 2 \\
\hline 15 & Qianfo Dong & 千佛洞 & Longdong, Gansu & $35.35495^{\circ} \mathrm{N}$ & $107.5003^{\circ} \mathrm{E}$ & Tang & Late & 2 \\
\hline 16 & Zhangba Si & 丈八寺 & Longdong, Gansu & $35.35924^{\circ} \mathrm{N}$ & $107.4819^{\circ} \mathrm{E}$ & Northern Wei & Early & 2 \\
\hline 17 & Bei Shiku & 北石窟 & Longdong, Gansu & $35.60972^{\circ} \mathrm{N}$ & $107.5333^{\circ} \mathrm{E}$ & Northern Wei & Early & $3 a$ \\
\hline 18 & Xumi Shan & 须弥山 & Guyan, Ningxia & $36.27881^{\circ} \mathrm{N}$ & $105.9873^{\circ} \mathrm{E}$ & Tang & Late & $3 a$ \\
\hline 19 & Longmen Shiku & 龙门 & Luoyang, Henan & $34.55607^{\circ} \mathrm{N}$ & $112.4707^{\circ} \mathrm{E}$ & Northern Wei & Early & 2 \\
\hline 20 & Mengshan Dafo & 蒙山大佛 & Taiyuan, Shanxi & $37.78179^{\circ} \mathrm{N}$ & $112.4382^{\circ} \mathrm{E}$ & Tang & Late & $3 a$ \\
\hline 21 & Tianlong Shan & 天龙山 & Taiyuan, Shanxi & $37.73591^{\circ} \mathrm{N}$ & $112.3774^{\circ} \mathrm{E}$ & Northern Wei & Early & 2 \\
\hline 22 & Yungang Shiku & 云冈 & Datong, Shanxi & $40.11004^{\circ} \mathrm{N}$ & $113.1219^{\circ} \mathrm{E}$ & Northern Wei & Early & 2 \\
\hline
\end{tabular}




\begin{tabular}{|c|c|c|c|c|c|c|c|c|}
\hline Map no. & Cave temple & 中文名 & Location & Northing* & Easting & Dynastic dating & Phase & Visibility \\
\hline 23 & Huangze Si & 皇泽寺 & Guangyuan, Sichuan & $32.44143^{\circ} \mathrm{N}$ & $105.8106^{\circ} \mathrm{E}$ & Tang & Late & $3 b$ \\
\hline 24 & Qianfo Ya & 千佛崖 & Guangyuan, Sichuan & $32.47146^{\circ} \mathrm{N}$ & $105.8414^{\circ} \mathrm{E}$ & Northern Wei & Early & 2 \\
\hline 25 & Beikan Shiku Si & 北弇寺 & Bazhong, Sichuan & $31.86598^{\circ} \mathrm{N}$ & $106.7699^{\circ} \mathrm{E}$ & Tang & Late & $3 b$ \\
\hline 26 & Bamiao Wofo & 八庙卧佛 & Anyue, Sichuan & $30.30231^{\circ} \mathrm{N}$ & $105.316^{\circ} \mathrm{E}$ & Tang & Early & 1 \\
\hline 27 & Beishan Shiku & 北山寺 & Dazu, Chongqing & $29.71341^{\circ} \mathrm{N}$ & $105.7068^{\circ} \mathrm{E}$ & Late Tang & Early & 1 \\
\hline 28 & Lvxian Ya & 吕仙崖 & Rongxian, Sichuan & $29.54681^{\circ} \mathrm{N}$ & $104.4855^{\circ} \mathrm{E}$ & Late Tang & Early & $3 a$ \\
\hline 29 & Gexian Shan & 葛仙山 & Zigong, Sichuan & $29.44081^{\circ} \mathrm{N}$ & $105.027^{\circ} \mathrm{E}$ & Mid-Late Tang & $?$ & $3 a$ \\
\hline 30 & Pusa Shi & 菩萨石 & Zigong, Sichuan & $29.35419^{\circ} \mathrm{N}$ & $104.7104^{\circ} \mathrm{E}$ & Late Tang & Early & 2 \\
\hline 31 & Qianfo Ya & 千佛崖 & Zigong, Sichuan & $29.35336^{\circ} \mathrm{N}$ & $104.7108^{\circ} \mathrm{E}$ & Mid-Late Tang & ? & 2 \\
\hline 32 & Houlong Shan & 后龙山 & Rongxian, Sichuan & $29.53497^{\circ} \mathrm{N}$ & $104.3526^{\circ} \mathrm{E}$ & Song & Late & 2 \\
\hline 33 & Dafo $\mathrm{Si}$ & 大佛寺 & Rongxian, Sichuan & $29.45694^{\circ} \mathrm{N}$ & $104.4285^{\circ} \mathrm{E}$ & Song & Late & $3 b$ \\
\hline 34 & Longdong & 龙洞 & Rongxian, Sichuan & $29.45444^{\circ} \mathrm{N}$ & $104.4289^{\circ} \mathrm{E}$ & Mid-Late Tang & $?$ & 1 \\
\hline 35 & Jinbi Ya & 金碧崖 & Rongxian, Sichuan & $29.45428^{\circ} \mathrm{N}$ & $104.4188^{\circ} \mathrm{E}$ & Tang & Mid & $3 b$ \\
\hline 36 & Erfo Si & 二佛寺 & Rongxian, Sichuan & $29.45306^{\circ} \mathrm{N}$ & $104.4199^{\circ} \mathrm{E}$ & Mid-Late Tang & $?$ & $3 b$ \\
\hline 37 & Gufo Si & 古佛寺 & Rongxian, Sichuan & $29.45822^{\circ} \mathrm{N}$ & $104.4093^{\circ} \mathrm{E}$ & Tang & Late & $3 b$ \\
\hline 38 & Fo'er Bei & 佛耳坝 & Rongxian, Sichuan & $29.39253^{\circ} \mathrm{N}$ & $104.2757^{\circ} \mathrm{E}$ & Middle Tang & Early & 2 \\
\hline 39 & Fo'er Wan & 佛耳湾 & Rongxian, Sichuan & $29.39003^{\circ} \mathrm{N}$ & $104.2801^{\circ} \mathrm{E}$ & Late Tang & Late & 2 \\
\hline 40 & Oupeng Wan & 窝棚湾 & Rongxian, Sichuan & $29.39161^{\circ} \mathrm{N}$ & $104.2834^{\circ} \mathrm{E}$ & Late Tang & Early & $3 a$ \\
\hline 41 & Pengshi Wan & 棚石岩 & Rongxian, Sichuan & $29.39167^{\circ} \mathrm{N}$ & $104.4894^{\circ} \mathrm{E}$ & Mid-Late Tang & $?$ & $3 a$ \\
\hline 42 & Laimou Qianfo & 来牟千佛 & Rongxian, Sichuan & $29.52067^{\circ} \mathrm{N}$ & $104.1889^{\circ} \mathrm{E}$ & Late Tang & Late & 2 \\
\hline 43 & Leshan Buddha & 乐山大佛 & Leshan, Sichuan & $29.54694^{\circ} \mathrm{N}$ & $103.7693^{\circ} \mathrm{E}$ & Late Tang & Late & $3 b$ \\
\hline
\end{tabular}

*GPS points are presented in decimalised degrees; 'Phase' refers to phase of Buddhist development in the region. 

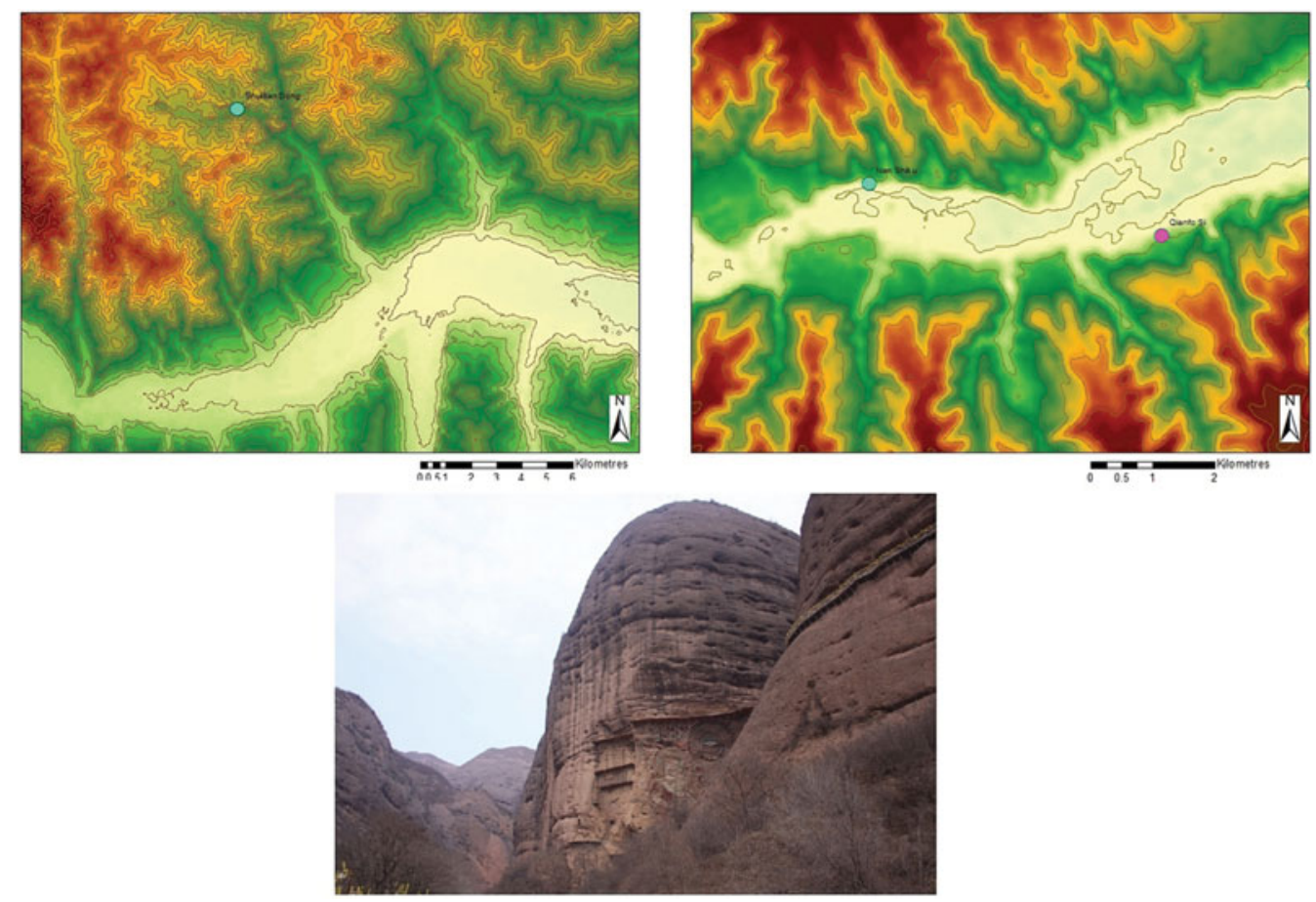

Figure 2. Left and bottom) Shuilian Dong, relief map and photograph of site location; right) Nan Shiku (blue circle) and Qianfo Si (pink circle), relief map.

which includes its height upon the cliff. Such cave-temples would often also have had external wooden structures in front of them, which may have influenced their visibility. Scholarship on these is still in its nascent stages, even though some studies have been published in recent years (e.g. Peng 2017).

The visibility of a site is based on an assessment of its position within the physical landscape. The sites have been divided into three types:

1) Not visible—set into narrow valleys or coves, and not visible from outside these formations (Figure 2 left and bottom).

2) Visible on approach — set onto the sides of broader valleys, or carved into rocky crags half way to two-thirds of the way up a mountain. These sites are not hidden, but they do not dominate the landscape. These are either constructed alongside probable trade routes, or might historically have been concealed by vegetation (Figure 2 right).

3) Prominent location-highly visible sites that dominate the landscape. This type is subdivided into sites that were in isolated locations and those that were visible from a settlement known to be present at the time of the construction of the site.

a. Not visible from a known ancient settlement (Figure 3 left).

b. Visible from a known ancient settlement (Figure 3 right). 

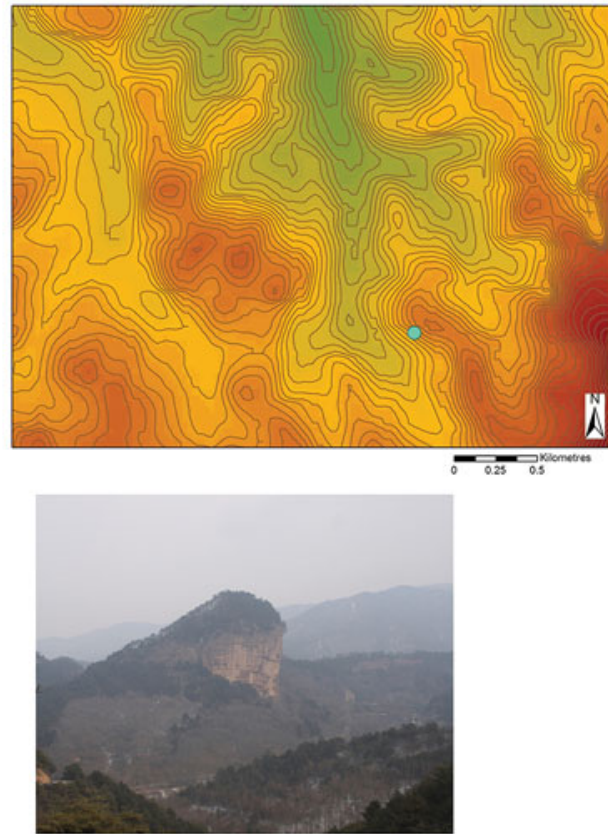
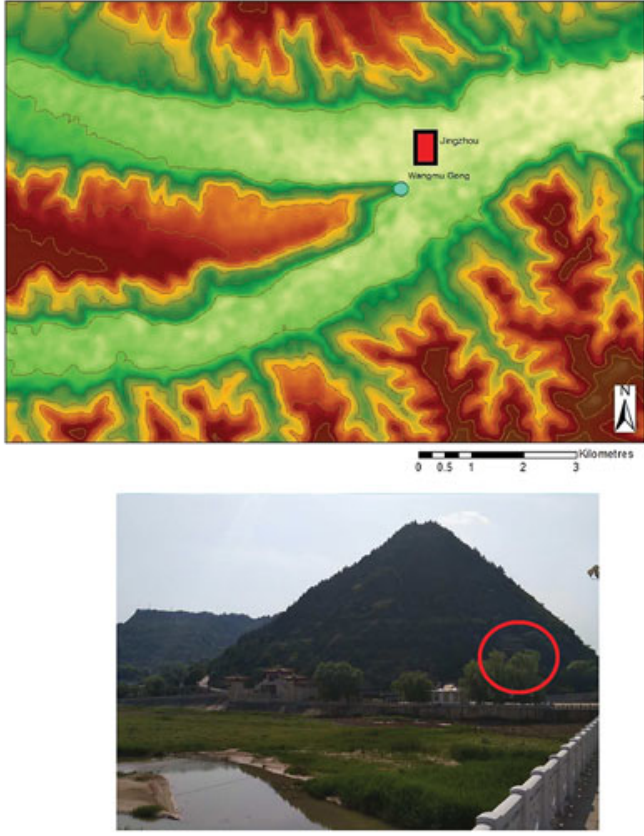

Figure 3. Left) Maiji Shan, relief map and photograph of site location; right) Wangmu Gong, relief map and photograph of site location. The sites are represented on the relief maps by blue circles.

Although there is no clear differentiation in the distribution of visibilities when all sites are plotted together, a clear trend is seen when divided into pre-Tang and Tang (Figure 4). Over 35 per cent of pre-Tang sites are located in non-visible locations, compared to only 11 per cent in the Tang. Conversely, 18 per cent of pre-Tang sites are in prominent locations, with 58 per cent in the Tang. Only 33 per cent of prominent sites are visible from an ancient settlement in the pre-Tang sample, and 86 per cent in the Tang.

As Buddhism did not arrive in all areas of China at the same time, the sites were also, for the purposes of this article, divided into early and late for their region. In the north, the early phase is the Northern and Southern Dynasties, and the later phase is the Tang; in the south, the early phase is the High and Middle Tang, and the later phase is Late Tang. This makes the variations clearer (Figure 5), with 37 per cent of sites in the early period in non-visible locations, compared to 0 per cent in the late period. In comparison, 21 per cent of early sites are in prominent locations, compared to 62 per cent in the late period. Twenty per cent of the early-period prominent sites are visible from an ancient settlement, compared to 75 per cent in the later period.

The statistical significance of both sets of data (pre-Tang to Tang, and early to late) was tested using a two-way chi-squared test and found to be significant at 95 per cent. The early to late classification gave a higher level of significance than the pre-Tang to Tang, suggesting that this distinction is meaningful.

In addition, there is a site type that is present in the earlier period but absent in the later one. These are extremely remote sites that are set into extraordinary landscapes (non-visible (C) Antiquity Publications Ltd, 2017 


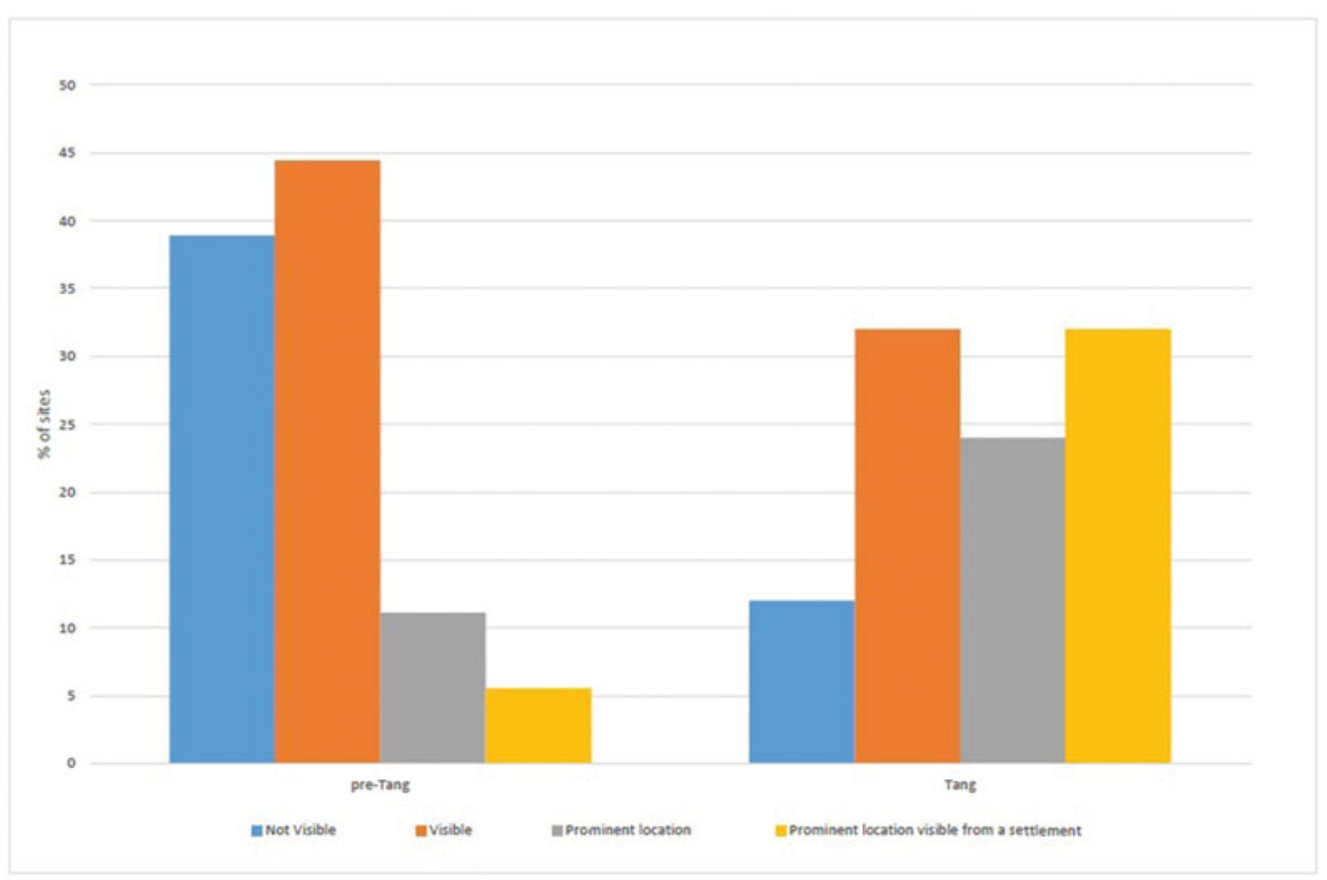

Figure 4. Bar chart showing the visibility of sites against time period.

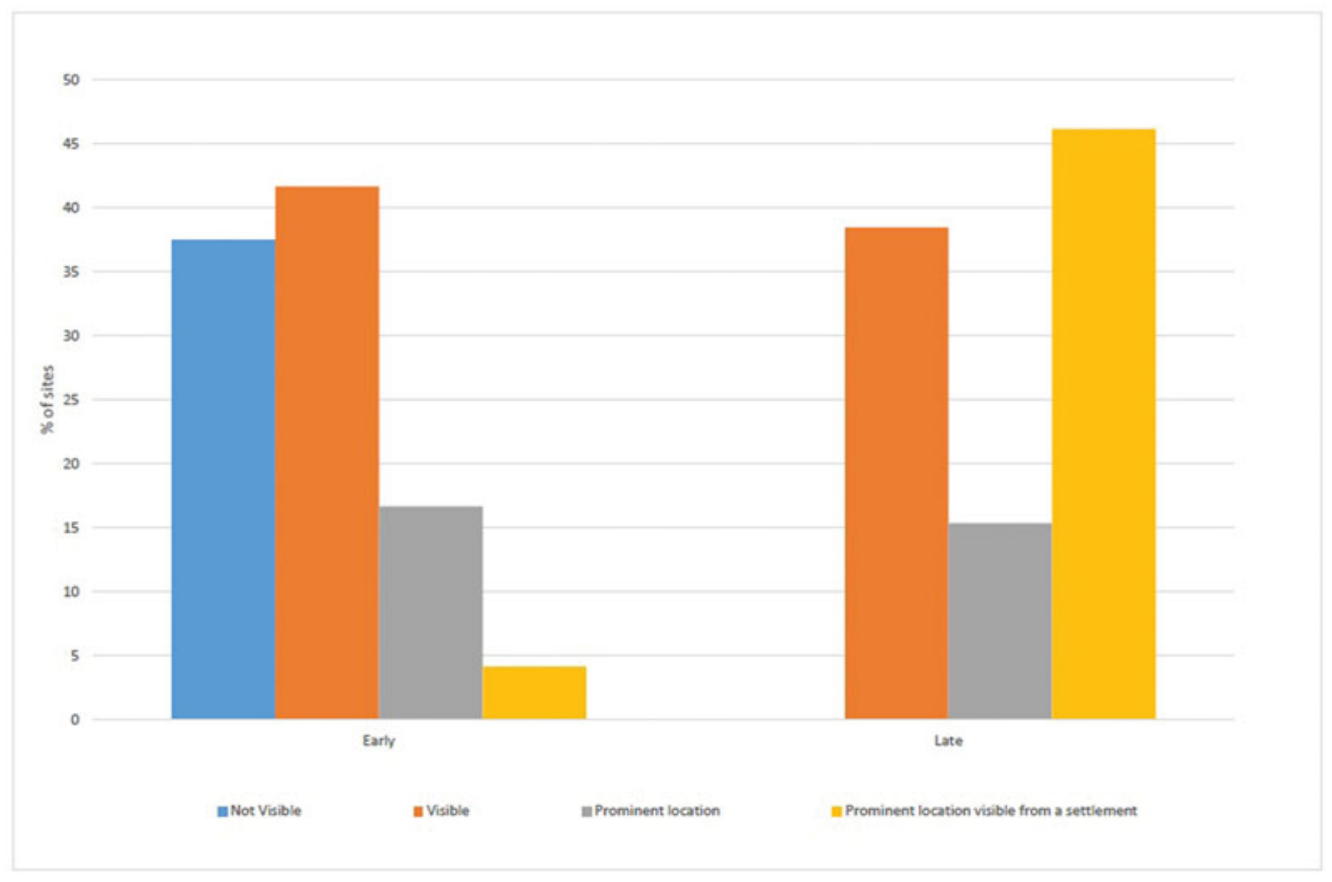

Figure 5. Bar chart showing the visibility of cave-temples when divided according to phase of Buddhist development.

(C) Antiquity Publications Ltd, 2017 
classification). Such sites might have been constructed to draw upon, or perhaps subjugate, the spiritual power that these locations held within previous religious practices.

The construction of cave-temples in exceptionally prominent locations in the later phase appears to represent Buddhism at a time when it was no longer perceived as an alien religion. This increased site visibility could be interpreted as a declaration of Buddhist presenceperhaps a clear message of 'we are here and we protect you'.

These data support the initial hypothesis that the visibility of sites increases over time, but would indicate that it is related to the duration of Buddhism's presence in a region, rather than to absolute dates. This represents a preliminary step in putting these sites into their archaeological context.

\section{References}

Peng, M.H. 2017. Yungang Shikude Yingzao Gongcheng. Beijing: Wenwu.
Rhie, M.M. 2010. Early Buddhist art of China and Central Asia. Leiden: Brill.

WeI, Z. 2013. Weijin Nanbeichao Kaogu. Beijing: Peking University Press. 